\title{
Chapter 8 \\ Poor but Sexy? Berlin as a Context for Social Innovation
}

\author{
Benjamin Ewert
}

\subsection{Introduction}

Since Germany's reunification, Berlin has benefitted much from the myth of being "poor but sexy" (Mayor Wowereit in Frey 2003). The popular slogan, referring to the coexistence of deprivation and creativity in the city, was a good expression of the Berlin zeitgeist. Representing a kind of social compromise, Berlin promised "a good life for little money" for everyone, not at least because of low rents.

Hence, for many years, Berlin provided a favourable context for social innovation. From the 1960 s onwards, the former "front city" had been an eldorado for agents of change - bohemians, alternative and creative people — who came to West Berlin to pursue unconventional solutions to everyday problems. For instance, new forms of parent-run childcare stem from that time, as do participatory schemes for housing and urban renewal. However, those attempts at "making a difference" took place against a backdrop of huge state subsidies and redistributive welfare policies that provided leeway for "social experimentalism". Today's social innovations in Berlin are still shaped by this "cultural heritage", which has contributed much to the city's self-promotion as "poor but sexy". However, as it is the main argument of this chapter, Berlin's innovative capital may dry up in the near future due to the reemergence of social challenges that tend to eclipse the rewards and improvements emanating from social innovation. Because Berlin is no longer an "island" but a part of international relations under the rising pressure of global investment and capitalist dynamics, traditional social problems are back: a sharper divide between rich and poor people, insecurity and gentrification. As a result, the space for many citizens that could afford to live in Berlin on a low income is increasingly being squeezed. For them, the "new" Berlin entails no promises in terms of wages, personal development and social security.

\footnotetext{
B. Ewert $(\triangle)$

Heidelberg School of Education, Voßstraße 2, 69115 Heidelberg, Germany

e-mail: ewert@heiedu.uni-heidelberg.de

(C) The Author(s) 2016

T. Brandsen et al. (eds.), Social Innovations in the Urban Context,

Nonprofit and Civil Society Studies, DOI 10.1007/978-3-319-21551-8_8
} 
This chapter deals with Berlin's changing context factors to foster social innovation. In this respect, two major developments are crucial: On the one hand, state welfare policies have become much "leaner", i.e. efficiency oriented and risk averse, conceiving every investment as something that has to "pay off" in the future. On the other hand, the scope of markets has colonized many life worlds and settings (making Berlin to a "catwalk" for flashy lifestyles and tastes) that once provided the "creative class" (Florida 2009) with shelter and inspiration. Welfare innovations for social cohesion eke out a niche existence, struggling continuously for resources and public attention. In short, it remains to be seen whether welfare politics and social innovators will find new interplays for remaking social policies innovative and powerful, or whether social innovations and their support will become limited to subsidizing rescue and emergency programmes.

This chapter is divided into four parts. Part one (Sect. 8.2) focuses on theoretical strands that have to be addressed in order to make a context-centred perspective valuable in the analysis of social innovation. Part two (Sect. 8.3) deals with Berlin and city policies as a specific context for social innovation. Part three (Sect. 8.4) of the chapter sheds light on the general shift in Berlin from a traditional social policy to a policy of modernization that allows limited space and resources for social innovation. Part four (Sect. 8.5) relates the theoretical insights concerning context factors to the empirical findings.

\subsection{What Makes a Context-Centred Perspective Valuable?}

Setting aside all their differences, major theoretical concepts in policy analysis (Majone 1997; Sabatier 1998) share one basic assumption: Ideas, orientations and values in politics and policies matter a great deal. They make a decisive difference when it comes to a context-centred perspective (see for an overview Pollitt 2013) that sheds light on the ways in which local welfare systems and political administrative systems (PAS) cope with cultural, social and economic challenges that co-shape the urban context. For instance, most of the innovative approaches, studied in Berlin, are kind of knot-points, where needs, ideas and aspirations assume concrete organisational forms that differ from the local mainstream of policies in place. Yet at the same time, they are interrelated with them, be it due to the fact that an innovation can also be part of a reform approach in the PAS, co-funded by it or simply linked to it through the criticism, suggestions and messages that come from the innovators.

In order to outline the orientations and values that are shaping the Berlin context and discussing these orientations in relation to innovative approaches in housing, childcare and family care and employment policies, three particular concerns guide the analysis:

- Plurality of discourses: To understand the interplay of politics and social innovations, it is important to view them within the tension field formed by the juxtaposition and rivalry of different discourses (see Schmidt 2010) — as, for example, one that is very much about classical welfare issues, another that is much more 
managerial and still another where concerns of autonomy, participation and pluralism prevail (Evers 2010). Berlin has always been characterized by competing concepts of "a better city" that were not exclusive but coexisted and stimulated each other. In other words, they all left their mark on the urban landscape. For instance, in the field of housing and urban revitalization a plurality of discourses has long meant that large-scale programmes, such as those to promote "careful urban renewal", pursued by the city government were challenged (or even subverted) by various citizen initiatives such as the squatter movement (Holm and Kuhn 2011). Similarly, alternative concepts for childcare (e.g. so-called Kinderladen pursuing an anti-authoritarian upbringing of children in West Berlin) and concerning working life (e.g. rejecting the use of "state dosh" for alternative projects in the field of social work) emerged from Berlin's counterculture.

- The impact of history: Practices and values that guide action and politics have been very much affected by the historical developments and experiences that make up the "multi-layered historicity of the present" (Haggrén et al. 2013). A tableau of coexisting values and policy orientations and reasoning about its possible changes can only be created when one takes account of these historical underpinnings. Thus Berlin, and in particular its local welfare policies, can only be understood against the backdrop of the changing history of the city. For instance, average rents in Berlin are still relatively low compared to other major German cities (e.g. Hamburg and Munich) because the housing supply was heavily subsidized by the federal state until the 2000s. Nevertheless, the steady rise of rents and its effect on the social mixture within inner-city districts has today become Berlin's most controversial issue. Likewise, developments in the field of employment may be misinterpreted without a healthy dose of historical evidence: While some regions in southern Germany (e.g. in some regions in Bavaria and Baden-Wuerttemberg) are heading towards full employment, unemployment in Berlin is still in the double-digit range. One reason for this is the inherited structural weakness of the local economy that is service based but lacks jobs in traditional industries (Allon 2013, p. 289). With regard to childcare and family care, Berlin remains a divided city (despite a process of gradual convergence) due to different policy legacies: In East Berlin (where childcare policies were characterized by a "work-centred approach" during German Democratic Republic (GDR) times), childcare coverage (and supply) for children aged 0-3 is significantly higher than in West Berlin, where traditionally there was part-time care for children aged 3-6 in kindergartens.

- Differences between policy fields: It is not only the difference between old and new, and left and right orientations that can be observed but also the specificity of discursive constellations in policy fields constituted by "'horizontal' and 'vertical' components" (Kendall 2003, p. 7), i.e. local and federal competences to change politics. While there may often be a kind of overarching narrative, shaped by national politics and dominating local coalitions, due to a number of factors, situations in policy fields may vary quite considerably. Moreover, innovative ideas, while backed by the community of experts in a policy field, may often be restricted by the locally prevailing general discourse or vice versa. 
For instance, the impact of a pronounced productivist discourse in the field of childcare emanating from the federal level implies fewer limits for innovative concepts at the local level compared to labour market politics where federal guidelines are much more rigid. Hence, local innovations in child and family policies such as family centres are promoted and supported by authorities because there is an overall agreement that "their time has come". On the other hand, Berlin's few innovative projects in the field of employment - in terms of style, approaches pursued and the addressing of users - have to be seen in sharp contrast to official, employability-guided policies.

The line of argument in this chapter takes place against the backdrop of this theoretical framework. If appropriate, references to single concerns will be made. Moreover, due to significant differences within policy fields, the empirical section of the chapter is structured by them (see Sect. 8.3).

\subsection{Context Factors in Berlin}

To analyse the interplay between welfare politics and social innovation in Berlin, a profound understanding of the local context is needed. Three factors, briefly introduced below, are crucial in this respect: the city's creative and innovation-friendly citizenry, the socio-spatial concept of the "Berlin mixture" and legacies of social policy. Despite significant differences within policy fields (e.g. due to federal legislation), these factors make up the sociocultural framework, including dominating attitudes and mentalities through which social innovation has appeared in Berlin.

\section{Creative Citizens}

Historically, Berlin's sociocultural attraction has been boosted by its special position during the era of division between East and West, its role in the times of the new social and cultural movements of the sixties and seventies and the dynamic that was set free in the aftermath of Germany's reunification (Häußermann and Kapphan 2009). All three phases swept large numbers of people, literally speaking "change agents", into the city who sustainably co-designed Berlin as a place for unconventional lifestyles and creative solutions for everyday challenges. The former West Berlin, in particular the district of Kreuzberg (Kil and Silver 2006), played host to the students' revolution and the new ecological, feminist and antiauthoritarian movements and their counterculture, becoming the ultimate vanishing point for dropouts, nonconformists and "artists of life" who built up a collective alternative model to West German mainstream culture by pursuing innovative social practices such as living in autonomous communities, working in cooperatives or establishing anti-authoritarian forms of childcare. At each turn and under changing conditions, the aspirations behind social and cultural innovations changed in colour and composition. Since the 2000 s, city marketers have promoted Berlin actively as a "metropolis of creativity" (Schmidt 2014) that seeks to give culturepreneurs "a stage set for their activities" (Colomb and Kalandides 2010, p. 185). 


\section{"Berlin Mixture"}

It is an open secret that "Berlin has always hosted poverty better than other European capitals" (Slobodian and Sterling 2013, p. 2). But what is this judgement based on? Against the backdrop of lower industrial development, a distinctive territorial and social mix characterizes Berlin where rich and poor people live loosely together. On the one hand, this mix refers to the sound balance of inhabitants in Berlin's numerous Kieze, a local synonym for integrated urban neighbourhoods. On the other hand, the term refers to a specific local settlement structure, supported by authorities, that allows the juxtaposition of housing facilities and local businesses. A combination of both aspects, a mixed structure of residents and settlements in the neighbourhoods, became known by the term "Berlin mixture" during the years of rapid industrial expansion in Germany in the middle of the nineteenth century and remains to this day.

\section{Social Policy Legacies}

Local authority policies had a huge impact on Berlin's urban and social development. Largely in the hands of social democrats (who have taken part in every administration since 1945 bar one), public servants have worked under the banner of "equality" and "social protection". However, Berlin's special status also has had to take account of the fact that, although until the 1960s Berlin was an example for classical, post-war welfare policies, West Berlin became "the front of the Cold War" after the building of the Berlin Wall in 1961 and was, therefore, heavily subsidized by the federal government in order to compensate for the city's weak economic situation and to remain competitive with East Berlin and the GDR. Traditionally, public authorities have been inclined to pursue large-scale development programmes known as "careful urban renewal" (1979-1987), "urban renewal areas" (since 1994) or "urban redevelopment scheme East and West" (since 2002).

In a nutshell, the lesson emanating from these contextual factors, especially in terms of their impact on innovations, can be summed up like this: Berlin had over the years been home to a juxtaposition of traditional local welfare politics and values with a strong sense of innovation and innovators focusing on values that were more to do with personalising welfare systems and opening them up to new lifestyles and aspirations. During the long period before reunification, the city was subject to limited growth pressure and served as "a window of the West", supported by considerable welfare subsidies, all of which made Berlin an affordable and rather secure place for both the large array of lower-income groups - "the scenic poor and the clever unemployed who make the city so attractive" (Slobodian and Sterling 2013 , p. 2) - and those groups that formed part of new social and cultural movements and searched for new forms of quality of life with different ideas about risks and chances. Now, under the rising pressure of international investment, capitalist dynamics are back and along with them greater inequalities, insecurity and gentrification. Classical social problems are now setting in. In times of financial crisis, the city government cannot mitigate these problems using the traditional means of social and urban policies. This represents a clear danger to the space and support enjoyed by innovators who sought to create a better quality of life and refine social support systems bottom-up. 


\subsection{Insights from Three Local Contexts of Social Policy}

What do these context factors mean for social policy in practice? What impact do historical developments and legacies have on today's structuring and design of different policy fields? Empirically, with a particular eye on social innovation and social cohesion, three areas were crucial for our research: housing and urban development, labour market policies and childcare and family care. With respect to the overall orientations and values that guide local politics in Berlin, the debates around issues of housing and urban development currently have the strongest link with the dominant political and public controversy around Berlin's development and the blend and balance of values that guide it. This section has therefore been placed first. After that, the sections that follow describe the situation in policy fields such as childcare and family care and labour market policies. Each section includes a separate subsection on "Spaces for Innovations", making references to routinebreaking initiatives and projects within the respective policy field.

In methodological terms, this chapter is based on 18 interviews with civil servants, policy makers and representatives from third-sector organizations and innovative projects in the district of Friedrichshain-Kreuzberg, which represents a kind of showcase for developments in Berlin as a whole. Additionally, a document analysis of local newspaper articles, party programs and city council minutes was carried out. Moreover, we draw on a transcript of a grassroots meeting organized in February 2013, documenting a lively debate between the experts mentioned above.

\subsubsection{The Context of Housing and Urban Planning}

Berlin is constantly growing. According to estimates, the city's population (3.53 million in 2013) will increase by about 7.2\% (250,000 people) by 2030 . The rising population leads directly to the question of where newcomers should live in the future. Today, there is a shortfall of about 428,000 affordable homes for Berlin's recipients of social assistance. While currently rents are rising everywhere in Germany, the situation in Berlin, where average rents of $7 € / \mathrm{m}^{2}$ are still much lower than in Munich $\left(9.99 € / \mathrm{m}^{2}\right)$, Stuttgart $\left(7.42 € / \mathrm{m}^{2}\right)$ or Cologne $\left(7.36 € / \mathrm{m}^{2}\right)$, is critical because the city has been traditionally a "paradise for tenants". No other major city in Germany has had such a generous amount of "cheap space" at its disposal-not only as a place for everyone to live but also as a place to realize new ideas of urban living through innovative projects. On the one hand, this kind of decadent charm and aura of decay made Berlin a "Mecca for the creative class" (Slobodian and Sterling 2013, p. 2). On the other hand, bohemians and hipsters - the harbingers of gentrification - were followed by "investors and real-estate interests" (Allon 2013, p. 299). Consequently, housing, ignored as a policy field for a decade, has moved to the top of the political agenda and with it a range of unresolved conflicts. The complexity of the issue concerns its interconnected dimensions of equality (housing 
as a social right), social cohesion (which depends on mixed neighbourhoods) and general priorities of urban planning (based on citizens' involvement or the prospect of profits).

\section{Old and New Challenges in Urban Planning}

In 2001, the Berlin Senate decided to downsize their social housing programmes to zero and embarked on a rigid austerity policy. Practically, the follow-up funding for social housing from the federal state of Berlin, substituting West Germany's subsidies after 1989, was abolished and housing stocks were privatized en masse. From 1990 till 2010, the number of state-owned dwellings shrank dramatically from 480,000 to 270,000 and with it the Berlin Senate's impact on the local housing market (Holm 2011).

Officially, this critical juncture (the end of federal subsidies and privatization of dwellings) was legitimized by the view that "Berlin has no housing problem but a poverty problem", as one interviewee put it. In 1999 the Berlin Senate reacted to early signs of urban decay and two-tier neighbourhoods by implementing "neighbourhood management" (NM) areas, an approach to "soft urban renewal" and social cohesion belonging to the federal programme "social city". In a sense, NM, rebuked by critics as a helpless attempt to compensate the previous social housing policy, ought to have been a remedy for the presumed losers from neoliberal urban development processes: the long-term unemployed, poor and/or poorly educated people, the elderly and migrants. By concentrating more on qualitative (e.g. social and economic conditions of neighbourhoods) than on quantitative problems (e.g. more social housing), NM has marked a paradigm shift in urban development policies (OECD 2003).

Nonetheless, in terms of traditional housing policies, the 2000s were, retrospectively, almost "wasted years" during which cost containment outweighed any attempts to regulate rents or expand the capacity of social housing. This had explosive social consequences, for instance, the displacement of long-term residents from inner-city districts (a process that started in 2011), which have hit Berlin politics catching it quite unprepared. Suddenly, the official line of reasoning, downplaying the existence of any problems by referring to the (relatively low) average level of rents and housing vacancies in outskirts of the city, conflicted harshly with the public perception: The loss of neighbours and friends forced to move into cheaper flats. In the face of these displacement processes, Mayor Wowereit's motto "there is no right to live in the city centre" (quote from 2011) seemed rather cynical, and the need for a new, post-austerity housing policy was clear for all to see. But how was it possible to reinvent social housing in a city that was simply "broke" and that has only 270,000 flats (Holm 2011) at its disposal? This shifts the perspective to a more fundamental question: How should public space be handled?

\section{Space for Innovations}

While questions of city planning remain an issue for professionals, a more public and more general debate on a revised property policy for Berlin has recently started. Calls for a structural policy change, claiming a balanced set of criteria for the tendering of urban property, which has been solely based on profit maximization in 
the past, came from actors outside the established political arena. Ad hoc groups of tenants who risked losing their homes and a citizen initiative called "Rethinking the City" have evoked fresh discussion on the old question "who owns the city". As a first success, Berlin's senator of finance announced a pilot project, providing for the sale of up to 14 state-owned properties for a fair market value to non-profit housing companies. However, many more far-reaching goals, such as more participation by citizens in the development of public property and a moratorium on all current property sales, are requested by the initiative. "It's impossible to change Berlin's property policy all at once; we therefore need a moratorium that allows public reasoning", says a speaker of the initiative.

The issue of ownerships concerns not only housing but also non-profit projects, promising "social dividends" instead of easy money, as in urban gardening. In this respect, Prinzessinnengärten in Kreuzberg are a glowing example of creative urban renewal. The project, which uses urban waste land on a temporary basis (meaning that the project may end abruptly if the city council decides to sell the area to an investor), has generated multidimensional returns for the district such as providing a green oasis, educating urbanites on the basics of gardening and bringing very different people together. "This is what it takes to maintain the Kiez", states Robert Shaw, co-founder of the Prinzessinnengärten, who claims planning security for the project. Franz Schulz, district mayor of Friedrichshain-Kreuzberg (from 2006 to 2013), supports the idea of changing public property policies. "Urban property has to be sold with regard to investors' concepts for neighbourhood development and requires dialogue with the citizens concerned in advance", says Schulz. The mayor refers to pioneering projects in his district such as the art and creative quarter Südliche Friedrichstadt. There tendering for vacant lots is based on the quality of the investors' concept of urban renewal in the first place and is linked to a structured consultation procedure involving residents, applicants and decision makers. The actual amount of the respective bid plays a role as well but only accounts for $40 \%$ of the final decision. Obviously, such innovative procedures of participatory tendering cannot stop large-scale gentrification processes; nevertheless, they have an immense symbolic value by setting a counterpoint to the ongoing reshaping of "previously marginal spaces like Friedrichshain-Kreuzberg" (Allon 2013, p. 299) into "centres of wealth generation, middle-class employment, and valuable real estate" (Allon 2013).

Another attempt at more sustainable urban development in FriedrichshainKreuzberg tries to bridge concerns of saving space and diversifying the local economy. For instance, a so-called owner salon has been invented-a regular occasion where small-business owners in distinctive neighbourhoods gather informally under the patronage of the unit for business promotion. The goal of such meetings is to sensitize owners, who normally have little "real" contact with the district and its residents, for social and economic concerns in the neighbourhood, in particular the loss of diversity in the local settlement structure (which characterized the "Berlin mixture" in the past) due to the process of gentrification. "Nowadays, letting a building to rich tenants and investment firms is much more lucrative than letting it to local businesses", states Martina Nowak, head of the district's unit for business promotion. Consequently, the district's colourful collection of residents, retail 
shops and service providers risks disappearing, which in turn may affect homeowners' long-term returns on investment. "Nobody, moves to Friedrichshain-Kreuzberg because of its uniformity; it's the district's vivid mixture that inspires newcomers", adds Ms. Nowak whose unit is searching for empty plots and vacant premises that might be interesting for start-ups and creative businesses. Since the existing potential has been largely exhausted, local owners' commitment to co-design the future of the district is of the utmost importance. In this respect, Planet Modular is a local role model: The alliance of small- and medium-size companies from the hobby and crafts sector has revitalized the local economy by building a huge "creative store" at the Moritzplatz in Kreuzberg. Furthermore, Planet Modulor is part of a creative network that aims to integrate economic, social and cultural projects into the urban environment.

\subsubsection{The Context of Child and Family Policy}

Essentially, the local public discourse on child and family policy in Berlin conforms to federal policy guidelines. Accordingly, an expansion of crèches and day-care places combined with family-minded approaches such as family centres are almost the only alternatives. Hence, local policies have been evaluated solely to the extent to which they conform to "good practice" as defined by newspapers and the parliamentary public. Critique or genuine local debate - where contradictory statements are reciprocally related to one another - do not exist; instead, local particularities (or "obstacles" to achieving the policy goals mentioned) are reported from time to time. In this respect, three facts make Berlin distinctive: First, Berlin is the "city of babies" with the highest birth rate of any German metropolis. Among Berlin's districts, Friedrichshain-Kreuzberg's baby boom is the biggest (with 11.9 births per 1000 inhabitants). Second, one third of all families in Berlin are "one-parent families" which in almost all cases are socio-economically deprived. Third, about one fifth of families are considered as "less educated" and, as such, reliant on support measures. As a result, questions of sufficient provision and (equal) access to childcare facilities make up the local contribution to the general German debate on child and family policy. Key values and recurrent issues in this context, expressed by interviewees and in official statements by stakeholders, are "equal opportunities", "choice", "early childhood education" and "more flexible time schedules and regulations" at childcare facilities.

At first glance, the situation concerning childcare arrangements in Berlin seems much better than elsewhere in Germany. The city charges minimal fees for childcare places. Moreover, the percentage of children being cared for in a kindergarten or crèche in Berlin is very high: $94 \%$ among children aged 3-6, 77\% among 2-yearolds and $49 \%$ among 1-year-olds. Thus Berlin is a national pioneer with regard to children aged $0-3$ visiting a crèche. However, local problems concern the distribution of childcare places available, flexible caring arrangements and low-threshold support for families under stress. With a special view on Friedrichshain-Kreuzberg, 
it is clear that district authorities pursue strong "family-oriented" policies. The diversity of local needs is regularly assessed through a very detailed analysis. For instance, the child and youth welfare office has built up a standing working group called "baby boom", after miscalculating the demand for kindergartens in the early 2000 s, in order to react to the district's increasing birth rates. In addition, the district is a pioneer within Berlin because it pursues integrated concepts such as family centres conceptualized according to the "early excellence approach" and involving parents closely (see e.g. Lewis 2011). However, there is a lack of supply with regard to crèches, kindergartens and family centres equally. "Currently, we are unable to satisfy families' demand for services", admits Thomas Harkenthal, head of the local child and youth welfare office. The department projects a shortfall of about 1600 childcare places until 2015. In practice, this scarcity undermines the claim for equal opportunities among all children - a key value of the local authority. Some local childcare providers take advantage of the imbalance between demand and supply by charging parents just to put them on the waiting list for a place at their facility or demanding admission fees of up to $500 €$. Others collect fees, up to $300 €$ per month, for "additional services" such as early language support, music or sport lessons. Although this de facto practice of social selection violates public law, anxious parents tend to be willing to pay extra charges.

\section{Space for Innovations}

Overall, there is strong local coalition between public servants and civil society actors in Friedrichshain-Kreuzberg to invent and pursue more complex and innovative approaches in childcare policies. Three examples of social innovation should be mentioned. First, family centres, recognized as very effective facilities for children and parents in the neighbourhood, are innovative institutions in the context of Friedrichshain-Kreuzberg. Nonetheless, family centres are still widely perceived by authorities as add-on arrangements rather than as regular service providers. In order to consolidate their position, family centres' services - for instance additional educational services for children or occasions for informal meetings for parentsrequire continuous financing (currently centres are run on 1-year-contracts) from the Berlin Senate. Second, the neighbourhood mothers project-migrants as mentors, bridging the gap between troubled (migrant) families and the requirements of public life - is a flagship project in the district, managed by the Diakonie, a welfare association. The work of the neighbourhood mothers project - despite being underfunded and time-limited - is especially welcomed as complementing support concerning the integration of migrant families. Furthermore, district authorities have committed themselves to take on some neighbourhood mothers, completing a vocational training as "social assistants", after the project runs out. A third innovation deals with women, especially lone mothers. They are supported by Frieda, a local women's centre. Like the neighbourhood mothers project, Frieda provides informal help based on the assumption that clients need more than a kindergarten place. Frieda not only advises lone mothers but provides several low-threshold services such as a café, regular breakfast meetings and excursions so that women who are often socially isolated can make new social contacts. 
As the interviewees representing the three innovations reported almost unanimously, cooperation with district authorities and councillors and, vice versa, with childcare and family care providers is marked by mutual understanding and very much focused on issues and problem-solving. For instance, heads of family centres and project leaders praise the district authorities for their support and local pragmatism (e.g. when dealing with legal requirements) but accuse the senate (which decides the budget for Berlin's family-minded policies) for its lack of action. Actually, the political clout of the local coalition for child and family issues at the district level remains rather weak. Both, project operators and district authorities are equally "supplicants" of the Senate that cannot do much except put forward arguments for more financial support. On the other hand, their powerlessness in terms of budget planning reinforces the bonding effect among local actors, who perceive themselves equally as victims of the Senate's austerity policy, which is regarded as family unfriendly.

\subsubsection{The Context of Employment}

Generally, the discourse on employment is, even more than the field of child and family policy, dominated by federal policies and decisions. The reasons for that are, on the one hand, the fact that the employment field is centrally regulated by the Federal Employment Agency (FEA) and its local branches and job centres and, on the other hand, the enormous impact of the Hartz reforms, which came into force in 2003. Especially, Hartz $I V$, a federal law that merged unemployment and social assistance and forces job seekers to accept any job that they are offered, represents a paradigm shift in the German labour market. As a result, almost any discourse on employment in Germany centres on the consequences of the Hartz reforms such as the implementation of activation schemes, the punishment of those who refuse to cooperate, the quality of labour and the special needs of children and youngsters with unemployed parents. Moreover, Hartz $I V$ recipients face strict housing regulations: For a single household, rent subsidies are capped to $415 €$ in Berlin. Given the overstretched housing market, this "frozen subsidy" banishes de facto the long-term unemployed from better neighbourhoods in the city centre.

Beyond these ongoing controversies, there is relatively little space for debate on the innovative features of the local labour market, and policy programmes that give employment issues a local flavour are few and far between. Browsing through Berlin newspapers, one easily gets the impression that the city combines many negative aspects of the contested labour market reforms of 2003. The city is dubbed "capital of the long-term unemployed" or "capital of the poor and uneducated", and this is (more or less) backed up by data: In 2011, 20.7\% of Berlin's population received Hartz IV benefits. Particularly problematic was the situation for youngsters, who face a local unemployment rate of $13 \%$ (twice as high as the German average) and children, since every third child lives on social transfer money. In addition, in 2012, 126,000 employees depended on substituting social benefits despite having a job, indicating a massive extension of the low-pay sector during the last years. 


\section{Space for Innovations}

Visions outlined for the whole city, attempting to reposition Germany's capital as one of Europe's truly global metropolitan areas, include for example a "new industrialization of Berlin", or the building of a "creative and sustainable city", where good labour is equally shared between all inhabitants. Berlin's creative economy also has its cultural roots in the new social movements that sprang up in the 1970s which promoted new forms of micro-solidarities and participatory concepts as an alternative to the much-criticized traditional forms of state-based solidarity (Evers 2010, p. 52). In contrast to the initiatives for employment mentioned above, such a perspective focuses on new concepts of growth and economic development and only indirectly on the creation of jobs. Instead, discourses such as the "creative economy" aim to change the dynamic of doing business and business promotion in a post-industrial age. However, there is a significant gap, which has not yet been filled by the political concepts of urban and social change, between the vague, cultural ideas of Berlin's future and the vast number of promising local projects (Schneekloth 2009). Boosting Berlin's creative class-e.g. music and fashion labels, clubs, ateliers but also IT start-ups and (social) media companies-has become a strategy within local economic policy since the 2000s. In the absence of strong traditional industrial sectors, local politics embrace "creativity" as a value and a vehicle for future economic growth. According to Senate authorities, Berlin's rising "creative cluster", which generates $16 \%$ of the city's overall economic output per year ( 25 billion $€$ ), employs about 200,000 people. In order to consolidate this positive trend, a steering group, initiated by the Senate, is developing integrated policy recommendations and providing an online portal where entrepreneurs and creative workers can network across sectors. In particular, entrepreneurs and creative startups require infrastructural support, such as affordable office buildings that allow exchange between creative workers. Due to the enormous dynamism of the creative economy, leaving Berlin for another, more favourable, business location is a permanent option for start-up companies. The problem of the Senate's current "cluster management" is its relative blindness to the local conditions for creative entrepreneurialism. A "creative urban wonderland", as one interviewee remarked mockingly, needs more than an "ultimate master plan"; above all, a flourishing of creative business ideas needs local spaces for entrepreneurial leeway.

In conclusion one might say that the example of Berlin demonstrates that unemployment as an issue can be tackled from a number of perspectives: as a side effect of low economic dynamism, as a structural problem with a long local history, as a challenge to create better transitions from schools and vocational trainings to the labour market and, finally, from the perspective of reintegrating people into the existing labour market (public and private). In Berlin, employment policy is very much focused on the employability-oriented job centre approach, while more complex approaches that involve new concepts for growth and sustainable jobs have, so far, been secondary.

What are the main differences between local innovations - such as "job explorer", a project in Friedrichshain-Kreuzberg that matches local companies and pupils at an early stage - and mainstream employment policies? First, projects for labour 
market integration operate at the district level and focus on the particularities of the local context, while the job centre pursues large-scale, standardized programmes. Second, local approaches deal with unemployed people in groups, acknowledging that they are part of a local community, while mainstream policies address jobseekers as individuals whose social relationships are rather irrelevant. Third, complex approaches offer tailor-made and personalized support packages, while the portfolio of the job centre is limited to managerialist and impersonal devices. To sum up, the key difference concerns the overall perspective of the employment policy: Does it combine aspects of social and labour market integration or is it reduced to the principle of employability?

\subsection{Summary and Conclusions}

Mayor Wowereit's dictum of 2003 that Berlin is "poor but sexy" seems outdated and appears rather shallow today. Instead, one may conclude without cynicism that "Berlin has embraced an economic model that makes poverty pay" (Slobodian and Sterling 2013, p. 2) by attracting creative people and tourists in large numbers. At the same time, Berlin is well on its way to dry out the breeding grounds for its "sexiness", perceived as the city's constant capacity to invent alternative lifestyles and unconventional solutions to daily-life challenges. However, Berlin's unspoken promise to its citizens that a decent but also exciting life remains possible despite a lower income and a marginal social status was validated only for a finite period of history. In this respect, the impact of history cannot be overstated: The city's attractiveness rested much on its previous status as an "island of bliss" where real-world hardships were at least partly suspended and where people's self-realization was supported through low rents and generous social benefits. In the aftermath of Germany's reunification, Berlin's social appeal increased temporarily due to the doubling of space and, therewith, the emergence of additional niches for nonconformist ways of life and living. In addition, "constant change, experimentation, trend setting and creativity" (Colomb and Kalandides 2010, p. 184), which the city had produced before in abundance without making a fuss, became ennobled as "hallmarks of Berlin" (Colomb and Kalandides 2010). Retrospectively, it is difficult to identify at which point exactly Berlin's social beat got out of sync, though it must have been in the early 2000s when the city arrived on the brightly illuminated stage of the globalized world (Krätke 2001). From then on, the city's rare gift for embracing pluralism and innovation was no longer protected by historical particularities and privileges but contested by, above all, the same capitalist dynamics that have been observed in other metropolis many times before (see for an overview: Kazepov 2005).

However, this climate of comprehensive change has affected each area of social policy differently due to powerful discourses that shaped previous policies, historic crossroads and field-specific regulations. What conclusions can be drawn for Berlin from the empirical evidence compiled in this chapter? Once more, the answers vary significantly in each policy field. 
Changes in the field of housing are the most severe and irreversible in the short term. The selling off of state-owned dwellings to private investors during the early 2000s has reduced the Berlin Senate's room for manoeuvre to reinvent a social housing policy drastically. What is more, city authorities have developed no new strategies for mitigating the problem of rising rents and scarce living space. Instead, they stick to rather "mechanical master plans" that are doomed to failure because of their inability to react to the diversity of the urban landscape. Innovative approaches do exist, such as the piecemeal restructuring of Berlin's inner-city districts in order to use space resources more efficiently, but the Berlin Senate does not support them. Meanwhile, the crowding out of tenants in inner-city districts like FriedrichshainKreuzberg is intensifying.

Despite also being affected by austerity policies and rising demand, the situation is different in the field of childcare and family care. Berlin benefitted much from the political and cultural shift in this field, as shown in the expansion of crèches decreed by federal legislation and the increased international attention to discourses such as those on "early childhood education" (Moss 2008) and "family-minded policies" (Clarke and Hughes 2010). Moreover, existing innovative offers, such as family centres or neighbourhood mothers, enrich the local provision of services. However, what is still missing is a clear commitment, in terms of long-term financing, from the Berlin Senate to integrate such innovations in the regular local welfare system. In the face of rising social inequality and the creeping disintegration of the "Berlin mixture", which guaranteed a certain level of social cohesion in the past, future investment in complementary and preventative childcare and family care services seems inevitable.

In Germany, the field of employment is regulated by the FEA in a highly topdown manner. Consequently, attempts to implement labour market integration in a "different way" are hardly possible without support by and cooperation with FEA branches or job centres. However, just a few small-scale projects (e.g. "Neighbourhood Mothers" or "Job Explorer") pursuing an innovative approach towards work integration have been devised by joint efforts. What is also missing is an integrated approach to deal with the growing urban underclass (e.g. uneducated migrants and youngsters, bohemians, single parents and long-term trainees). Current initiatives by the Berlin Senate are of little help for local jobseekers. Instead, ambitious attempts to re-establish the city as a hub for services and the creative economy are attracting mobile and better-educated people in the first place. Once more, local projects are the most promising, such as those that stimulate entrepreneurialism (see e.g. "Kreuzberg acts", Chap. 15 of this volume) and thereby help people to benefit from booming sectors such as the creative industry, healthcare or tourism.

Finally, the question remains whether Berlin remains to be a "daredevil social experiment" (Schmidt 2014) where social innovations of the future will be developed, tested and promoted. Much will depend on the city government's capacity to forge a new framework of innovation politics that goes beyond opportunistic support and short-term subsidies for projects that are useful on a temporary basis. Such politics requires a risk-taking culture, financial support and, above all, an understanding that innovators need free space for experimentation-both physically and mentally. 
Open Access This chapter is distributed under the terms of the Creative Commons AttributionNonCommercial 4.0 International License (http://creativecommons.org/licenses/by-nc/4.0/), which permits any noncommercial use, duplication, adaptation, distribution and reproduction in any medium or format, as long as you give appropriate credit to the original author(s) and the source, a link is provided to the Creative Commons license and any changes made are indicated.

The images or other third party material in this chapter are included in the work's Creative Commons license, unless indicated otherwise in the credit line; if such material is not included in the work's Creative Commons license and the respective action is not permitted by statutory regulation, users will need to obtain permission from the license holder to duplicate, adapt or reproduce the material.

\section{References}

Allon, F. (2013). Ghosts of the open city. Space and Culture, 16(3), 288-305.

Clarke, H., \& Hughes, N. (2010). Introduction: Family minded policy and whole family practiceDeveloping a critical research framework. Social Policy and Society, 9(4), 527-531.

Colomb, C., \& Kalandides, A. (2010). The 'be Berlin' campaign: Old wine in new bottles or innovative form of participatory place branding? In G. Ashworth \& M. Kavaratzis (Eds.), Towards effective place brand management. Branding European cities and regions (pp. 173-190). Cheltenham: Edward Elgar.

Evers, A. (2010). Civicness, civility and their meanings for social services. In T. Brandsen, P. Dekker, \& A. Evers (Eds.), Civicness in the governance and delivery of social services (pp. 4166). Baden-Baden: Nomos.

Florida, R. (2009). The rise of the creative class: Revisited. New York: Basic books.

Frey, G. (2003). Lassen Sie uns über Geld reden... Klaus Wowereit. Focus Money, 46, 90. www. focus.de/finanzen/boerse/aktien/moeny-talk-lassen-sie-uns-ueber-geld-reden-_aid_249988. html. Accessed 23 Nov 2015.

Haggrén, H., Rainio-Niemi, J., \& Vauhkonen, J. (2013). Multi-layered historicity of the present. Helsinki: Department of Political and Economic Studies, University of Helsinki. https://helda. helsinki.fi/bitstream/handle/10138/40338/Multi-layered_historicity_Final.pdf?sequence=1 . Accessed 27 Nov 2014.

Häußermann, H., \& Kapphan, A. (2009). Berlin: From divided to fragmented city. In F. E. I. Hamilton, K. D. Andrews, \& N. Pichler-Milanović (Eds.), Transformation of cities in Central and Eastern Europe. Towards globalization (pp. 189-222). Tokyo: United Nations University Press.

Holm, A. (2011). Wohnungspolitik der rot-roten Regierungskoalition in Berlin. In I. A. Holm, K. Lederer, \& M. Naumann (Eds.), Linke Metropolenpolitik. Erfahrungen und Perspektiven am Beispiel Berlin (pp. 92-112). Münster: Westfälisches Dampfboot.

Holm, A., \& Kuhn, A. (2011). Squatting and urban renewal: The interaction of squatter movements and strategies of urban restructuring in Berlin. International Journal of Urban and Regional Research, 35(5), 644-658.

Kazepov, Y. (2005). Cities of Europe. Oxford: Blackwell Publishing.

Kendall, J. (2003). The voluntary sector. London: Routledge.

Kil, W., \& Silver, H. (2006). From Kreuzberg to Marzahn. German Politics and Society, 24(4), 95-121.

Krätke, S. (2001). Berlin: Towards a global city? Urban Studies, 38(10), 1777-1799.

Lewis, J. (2011). From sure start to children's centres: An analysis of policy change in English early years programmes. Journal of Social Policy, 40(1), 71-88.

Majone, G. (1997). From the positive to the regulatory state: Causes and consequences of changes in the mode of governance. Journal of Public Policy, 17(2), 139-167. 
Moss, P. (2008). Markets and democratic experientialism. Two models for early childhood education and care. Bertelsmann Foundation. http://www.bertelsmann-stiftung.de/bst/de/media/ xcms_bst_dms_24015_2.pdf. Accessed 27 November 2014

OECD. (2003). Urban renaissance Berlin: Towards an integrated strategy for social cohesion. Paris: OECD Publications.

Pollitt, C. (2013). Context in public policy and management. The missing link? Cheltenham: Edward Elgar.

Sabatier, P. A. (1998). The advocacy coalition framework: Revisions and relevance for Europe. Journal of European Public Policy, 5(1), 98-130.

Schmidt, V. A. (2010). Taking ideas and discourse seriously: Explaining change through discursive institutionalism as the fourth 'new institutionalism'. European Political Science Review, 2(1), $1-25$.

Schmidt, T. E. (2014). Die Weltstadt der Kreativität. Die Zeit. 4 September. http://www.zeit. de/2014/37/berlin-innovation-wowereit-start-up. Accessed 28 Nov 2014.

Schneekloth, U. (2009). Leben zwischen Hartz IV und Kreativwirtschaft: Soziale Lage in Berlin. In G. Hertie-Stiftung (Ed.), Hertie Berlin Studie (pp. 41-75). Hamburg: Hoffmann und Campe.

Slobodian, Q., \& Sterling, M. (2013). Sacking Berlin. How hipsters, expats, yummies, and smartphones ruined a city. The Baffler. http://thebaffler.com/past/sacking_berlin. Accessed 27 Nov 2014. 